\title{
Effects of Soil Parent Material and Climate on the Performance of Vitis vinifera L. cvs. Sauvignon blanc and Cabernet Sauvignon - Part II. Climate, Leaf Analysis, Juice Analysis and Wine Quality
}

\author{
L.P. Shange*, W.J. Conradie \\ ARC Infruitec-Nietvoorbij ${ }^{1}$, Private Bag X5026, 7599 Stellenbosch, South Africa
}

Submitted for publication: February 2012

Accepted for publication: June 2012

Key words: Granite, shale, juice nitrogen, wine style

\begin{abstract}
A five-year investigation (2004/05 to 2008/09) was carried out in two Sauvignon blanc and two Cabernet Sauvignon vineyards in the Helderberg area, Western Cape, South Africa. Soils, derived mainly from granite and shale, were identified in each vineyard. Climatic parameters were measured, while leaves and juice were analysed. Experimental wines were prepared and evaluated annually. The nutritional status of the leaf blades and petioles was not affected by soil parent materials in a consistent pattern. Juice $\mathbf{N}$ of grapevines on the shale-derived soil was usually higher than that of vines on the granite-derived soil. The effect of soil parent material on Sauvignon blanc wine style appeared to have been more distinct at the locality where wine quality was highest. At this locality, wine from the grapevines on shale-derived soil (higher water-holding capacity) was best in 2004/05 (dry season), while the reverse was true in the 2007/08 season (wet). The style and/or quality of Cabernet Sauvignon wines were affected to a greater extent by differences in soil parent materials, relative to Sauvignon blanc. Differences were especially noticeable during the cooler and wetter seasons. Better drainage in the case of the granite-derived soils, due to the higher coarse sand fraction, may have played a positive role during these seasons.
\end{abstract}

\section{INTRODUCTION}

Soil parent material is considered to have a potentialdetermining effect on wine character and quality (Wilson, 1998). These effects are not directly on wine quality, since it is mainly the physical properties of a soil that determine quality through the effects of variables such as drainage, soil temperature and water availability on vine growth patterns (Conradie et al., 2002). According to research in Bordeaux (Seguin, 1983), classified vineyards owe their superiority to the ability of the soil to regulate the supply of water to the vines, rapidly draining excessive water but retaining sufficient water and releasing it at such a rate that, although the vines experience some stress towards ripening, this stress is not excessive. In the Coastal Region of South Africa, granite-derived soils were found to contain greater amounts of gravel and coarse sand, while shale-derived soils contained larger amounts of fine sand (Van Schoor, 2001; Conradie et al., 2002; Shange \& Conradie, 2012). Waterholding capacities generally tended to be highest in the shale-derived soils, while the effect of soil parent material on grapevine water constraints was fairly prominent in the drier seasons (Shange \& Conradie, 2012). Wine style and/ or quality may well be affected by these differences between granite-derived and shale-derived soils. However, the impact of soil parent material on wine style and/or quality under similar climatic, topographic and vineyard management practices has not yet been evaluated scientifically.

For grapevines, luxury uptake of $\mathrm{K}$ may affect red wine quality negatively by increasing juice $\mathrm{pH}$ (Somers, 1975; Conradie, 1994; Kodur, 2011), and altering the acid balance of the juice and wine (Conradie \& Saayman, 1989; Mpelasoka et al., 2003). In a study on Sauvignon blanc in the Coastal Region of South Africa, soils originating from phyllitic shales contained the lowest $\mathrm{K}$ levels compared to those from granite (Conradie et al., 2002). Wooldridge (1988) indicated that granite-derived soils are relatively rich in total $\mathrm{K}$, but possess little capacity to prevent its release, potentially resulting in a luxurious short-term supply of plant-available K. Levels of water-soluble soil $\mathrm{K}$ were generally greater in granite-derived than in shale-derived soils (Shange \& Conradie, 2012), suggesting that soil parent material may have an indirect effect on wine quality, through

\footnotetext{
${ }^{1}$ The Fruit, Vine and Wine Institute of the Agricultural Research Council

*Corresponding author: E-mail: shangep@arc.agric.za

Acknowledgements: Funding for this project was provided by Winetech and the Agricultural Research Council. The authors wish to thank the staff of the Soil and Water Science Division for technical assistance
} 
its relationship with $\mathrm{K}$ availability.

Root system development and efficiency could not be related directly to soil parent material and soil type (Shange \& Conradie, 2012). However, in most cases root density tended to be higher in granite-derived soils, while cane mass and yield also tended to be higher for grapevines on granitederived soils at some localities. The current research focuses on the effect of soil parent materials (granite and shale) on leaf and juice composition, as well as on wine style and/or quality, when climate, topography and vineyard management practices are similar.

\section{MATERIALS AND METHODS}

\section{Experimental vineyards and layout}

As previously described by Shange and Conradie (2012), the study was conducted over five seasons in four commercial vineyards (two x Sauvignon blanc and two x Cabernet Sauvignon) in the Helderberg Region, Western Cape, South Africa (Table 1). The Sauvignon blanc vineyards were designated as higher altitude (SH) and lower altitude (SL), and the Cabernet Sauvignon vineyards as were designated as $\mathrm{CH}$ and $\mathrm{CL}$ respectively. Locality $\mathrm{CH}$ was rain fed, whilst the others received supplementary drip irrigation (one or two irrigations per season). Within each vineyard, two soil parent materials were identified through identification of the underlying rock. The first parent material was granite of the Stellenbosch pluton, and the second was greywacke/ phyllitic shale of the Namibian Malmesbury Group (Theron et al., 1992). Experimental plots were selected on granitederived and shale-derived soils. Aspects and gradients are shown in Table 1. Further details concerning the experiment layout and cultivation practices were described in Shange and Conradie (2012).

\section{Climate}

Automatic weather stations were erected at each locality, except at SL, which was situated close to CL $(\approx 200 \mathrm{~m})$. Data were collected and processed by the Agricultural Research Council's Institute of Soil, Water and Climate (ISCW). Weather parameters such as temperature, rainfall and hours of sunshine were recorded. Hourly average data were used to calculate daily maximum, minimum and mean temperatures, number of hours with temperatures above $30^{\circ} \mathrm{C}$ and below $12^{\circ} \mathrm{C}$, and growing degree-days (Amerine \& Winkler, 1944). Weather stations were only erected during the course of the first growing season (2004/05), resulting in climatic data being unavailable for the first part of this season. Due to incomplete records, reliable data were also lacking for the 2005/06 summer months. In order to compare climatic conditions between the different seasons, data from a nearby weather station operated by the ISCW at Alto farm were used (Table 2). This station is situated at an altitude of 251 $\mathrm{m}$, at $34.0140^{\circ} \mathrm{S} ; 18.8558^{\circ} \mathrm{E}$, and therefore the location was comparable to that of the weather stations at the experimental sites (Table 1).

\section{Leaf analysis}

Approximately 30 leaves per plot were sampled directly opposite clusters during fruit set (four localities x two soil parent materials $\mathrm{x}$ five seasons). Leaves and petioles were separated immediately after sampling, oven dried, extracted with $1.0 \mathrm{M} \mathrm{KCl}$ and analysed for $\mathrm{N}, \mathrm{P}, \mathrm{K}, \mathrm{Ca}, \mathrm{Mg}$ and $\mathrm{Na}$ according to the standard methods of Campbell and Plank (1998) and Miller (1998) by an accredited commercial laboratory.

\section{TABLE 1}

Characteristics of four experimental vineyards planted to Sauvignon blanc and Cabernet Sauvignon in the Helderberg area, Western Cape, South Africa.

\begin{tabular}{|c|c|c|c|c|c|c|}
\hline Locality* & Scion/Rootstock & Soil parent material & Coordinates & Altitude (m) & Aspect & Slope $(\%)$ \\
\hline \multirow[t]{2}{*}{$\mathrm{SH}$} & $\begin{array}{l}\text { Sauvignon blanc/ } \\
110 \text { Richter }\end{array}$ & Granite & $\begin{array}{l}34.0254^{\circ} \mathrm{S} \\
18.8588^{\circ} \mathrm{E}\end{array}$ & 417 & NE & 1 \\
\hline & & Shale & $\begin{array}{l}34.0258^{\circ} \mathrm{S} \\
18.8584^{\circ} \mathrm{E}\end{array}$ & 411 & SW & 15 \\
\hline \multirow[t]{2}{*}{ SL } & $\begin{array}{l}\text { Sauvignon blanc/ } \\
99 \text { Richter }\end{array}$ & Granite & $\begin{array}{l}34.0216^{\circ} \mathrm{S} \\
18.8399^{\circ} \mathrm{E}\end{array}$ & 227 & NE & 9 \\
\hline & & Shale & $\begin{array}{l}34.0220^{\circ} \mathrm{S} \\
18.8417^{\circ} \mathrm{E}\end{array}$ & 230 & NE & 6 \\
\hline \multirow[t]{2}{*}{ CL } & $\begin{array}{l}\text { Cabernet Sauvignon/ } \\
110 \text { Richter }\end{array}$ & Granite & $\begin{array}{l}34.0188^{\circ} \mathrm{S} \\
18.8409^{\circ} \mathrm{E}\end{array}$ & 224 & W/NW & 1 \\
\hline & & Shale & $\begin{array}{l}34.0193^{\circ} \mathrm{S} \\
18.8435^{\circ} \mathrm{E}\end{array}$ & 238 & W/NW & 7 \\
\hline \multirow[t]{2}{*}{$\mathrm{CH}$} & $\begin{array}{l}\text { Cabernet Sauvignon/ } \\
110 \text { Richter }\end{array}$ & Granite & $\begin{array}{l}34.0303^{\circ} \mathrm{S}, \\
18.8450^{\circ} \mathrm{E}\end{array}$ & 270 & W/NW & 8 \\
\hline & & Shale & $\begin{array}{c}34.0302^{\circ} \mathrm{S}, \\
18.8443^{\circ} \mathrm{E}\end{array}$ & 280 & W/NW & 15 \\
\hline
\end{tabular}

*Sauvignon blanc (SH and SL) and Cabernet Sauvignon (CH and CL) experimental vineyards in Helderberg (S = Sauvignon blanc, $\mathrm{C}=$ Cabernet Sauvignon, $\mathrm{H}=$ High altitude, $\mathrm{L}=$ Low altitude). 


\section{Juice analysis}

The target sugar content value for harvesting was $22.5^{\circ} \mathrm{B}$ to $23.0^{\circ} \mathrm{B}$ for Sauvignon blanc and $23.0^{\circ} \mathrm{B}$ to $24^{\circ} \mathrm{B}$ for Cabernet Sauvignon. However, due to the occurrence of Botrytis cinerea during some seasons at SL, the grapes had to be harvested before this target value could be reached in order to obtain healthy grapes. During harvest, at least six randomly selected bunches were crushed in a hydraulic press to obtain juice at each plot (four localities x two soil parent materials x five seasons). This juice was analysed for total soluble solids (TSS) by using a temperature-compensated Abbé refractometer, $\mathrm{pH}$ (654 Metrohm pH meter) and total titratable acidity (TTA), where $50 \mathrm{~mL}$ juice was titrated with $0.333 \mathrm{M} \mathrm{NaOH}$ to $\mathrm{pH} 7.0$ and expressed as g tartaric acid/L. The rest of the juice was sent to an accredited commercial laboratory for $\mathrm{N}, \mathrm{P}, \mathrm{K}, \mathrm{Ca}, \mathrm{Mg}$ and $\mathrm{Na}$ analyses, which were carried out according to standard methods.

\section{Experimental wines}

For both Sauvignon blanc and Cabernet Sauvignon, approximately $40 \mathrm{~kg}$ to $60 \mathrm{~kg}$ of grapes were harvested from each plot, after which experimental wines were prepared by the research winery at ARC Infruitec-Nietvoorbij. Wine was made as described by Conradie (2001) and Myburgh (2011) for Sauvignon blanc and Cabernet Sauvignon respectively. Two replicates were fermented separately for each plot. Wines were bottled approximately four months after fermentation and then stored at $14^{\circ} \mathrm{C}$ until evaluation, which was about two months later. The tasting panel was made up of at least 14 wine tasters trained in the evaluation of Sauvignon blanc and Cabernet Sauvignon wines. Tasting took place in individual booths under white light and the wines were served in a completely randomised sequence. A $10 \mathrm{~cm}$ unstructured line scale was used by the judges to score specific aromatic parameters, from undetectable/ unacceptable $=0$ to prominent/excellent $=10$. This method is based on the standardised system of wine aroma terminology (Noble et al., 1987), which uses the following descriptors: fresh vegetative (green pepper, cut green grass, eucalyptus and mint), cooked vegetative (green beans, asparagus, olive and artichoke), dried vegetative (hay/straw, tea and tobacco), tropical fruit (pineapple, melon, banana and guava), dried fruit (strawberry jam, raisin, prune and fig) and spicy (liquorice, aniseed, black pepper and clove) characteristics for the description of Sauvignon blanc. Berry aroma (blackberry, raspberry, strawberry and black currant), as well as astringency, was also evaluated for Cabernet Sauvignon. General aroma intensity, fullness and overall wine quality were included for both cultivars.

\section{Statistical analysis}

Analysis of variance, using the five seasons as replicates, was performed on leaf and juice data by means of the general linear model (GLM) procedure of SAS statistical software version 9.1 (SAS, 2000). The Shapiro-Wilk test was performed to test for normality (Shapiro \& Wilk, 1965). The wine sensory attributes were subjected to a factorial analysis of variance and the repeated measurements over the five seasons were used as a subplot factor. Student's $t$ least significant differences were calculated at the $5 \%$ and $10 \%$

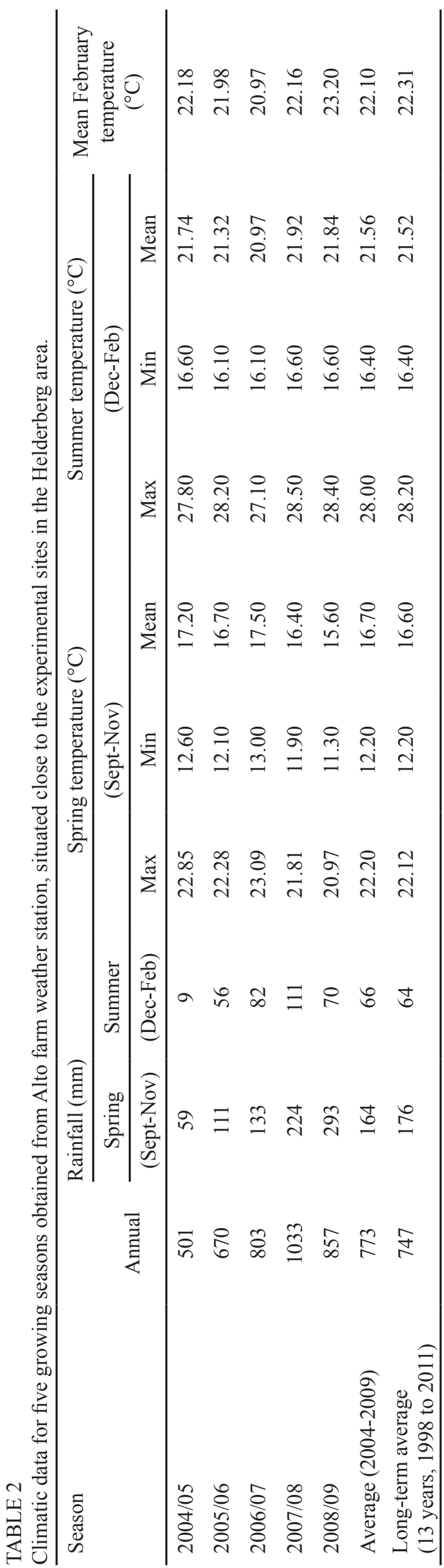


probability levels to compare treatment means (Snedecor \& Cochran, 1980).

\section{RESULTS AND DISCUSSION \\ Climate}

Average values for climatic parameters, over the five experimental seasons, were similar to the long-term average (LTA) calculated from 1998 to 2011, even though appreciable differences occurred between individual seasons (Table 2). The 2004/05 season was characterised by low rainfall, especially during spring (117 $\mathrm{mm}$ below average) and summer ( $55 \mathrm{~mm}$ below average). In this season, spring temperatures were marginally higher than the LTA, largely due to high temperatures during November (data not shown). Summer temperatures, as well as mean February temperatures, were close to normal (Table 2).

During the 2005/06 growing season, rainfall was fairly normal during the winter $(503 \mathrm{~mm})$ and summer, but spring was dry, with rainfall $65 \mathrm{~mm}$ below average. Temperatures were normal during spring and summer. For the 2006/07 season, annual rainfall was marginally higher than the LTA, spring was relatively dry (43 $\mathrm{mm}$ less than the LTA), while summer rainfall was approximately $20 \mathrm{~mm}$ higher than the LTA. Spring was relatively warm (mean temperature nearly $1^{\circ} \mathrm{C}$ above average), but summer temperatures (especially maximum temperatures) were lower than the LTA. During the 2007/08 season, total rainfall (1 $033 \mathrm{~mm}$ ) was the highest experienced during the experimental period. Apart from high rainfall during winter, spring (48 $\mathrm{mm}$ above average) and summer (47 $\mathrm{mm}$ above average) were also relatively wet. Temperatures were low in September, high in October and exceptionally low in November (data not shown). Summer temperatures were marginally higher than the LTA (Table 2). In the last growing season $(2008 / 09)$, total rainfall $(857 \mathrm{~mm})$ was $110 \mathrm{~mm}$ higher than the LTA. The latter was primarily due to wet conditions during spring, when precipitation was $117 \mathrm{~mm}$ higher than the LTA. Furthermore, mean and maximum temperatures during spring were $1.01^{\circ} \mathrm{C}$ and $1.15^{\circ} \mathrm{C}$ lower than the LTAs respectively, resulting in the coolest spring recorded during the investigation period. The month of January (2009) was also relatively cool (data not shown). The mean February temperature $\left(23.20^{\circ} \mathrm{C}\right)$ was the highest recorded during the investigation period (Table 2). This resulted in the mean temperature for the whole summer being close to normal.

Taking all of the above into consideration, the first two growing seasons (2004/05 and 2005/06) could be classified as dry, the third (2006/07) as normal and the last two (2007/08 and 2008/09) as wet. According to the spring temperatures, the 2008/09 growing season was cool, while 2004/05 and 2006/07 were the warmest. Mean summer temperatures varied by less than $1^{\circ} \mathrm{C}$ between the warmest (2007/08) and the coolest $(2006 / 07)$ seasons.

Summer temperatures at the experimental sites during the last three years of the investigation are shown in Table 3. In general, temperatures tended to be lower at SH (higher altitude) than at $\mathrm{CL}$ and $\mathrm{CH}$. This could be ascribed to lower minimum temperatures (e.g. number of hours with temperature $<12^{\circ} \mathrm{C}$ ) at $\mathrm{SH}$. Average temperatures were similar for $\mathrm{CL}$ and $\mathrm{CH}$ (Table 3 ). All three locations fall in Region III of the Winkler classification (Winkler et al., 1974), with indices ranging from 1700 to 1900 during the investigation period.

\section{Leaf analysis \\ Sauvignon blanc}

At the Sauvignon blanc localities, petiole N and K were not affected by soil parent material (Table 4). However, petiole $\mathrm{P}, \mathrm{Ca}$ and $\mathrm{Mg}$ were affected by the different soil parent materials. Petiole P of the grapevines on shale-derived soils was higher than that of vines on granite-derived soils at SL (Table 4). This result was in spite of soil $\mathrm{P}$ being similar in the upper soil layers (0 to $300 \mathrm{~mm}$ ) of the shale-derived and granite-derived soils, viz. $33 \mathrm{mg} / \mathrm{kg}$ and $37 \mathrm{mg} / \mathrm{kg}$ respectively. Petiole $\mathrm{Ca}$ and $\mathrm{Mg}$ of the grapevines on shalederived soils were higher than that of vines on the granitederived soils at both SH and SL (Table 4). In the case of SH, this corresponded to the exchangeable soil $\mathrm{Ca}$ and $\mathrm{Mg}$ levels, which were higher in the shale-derived $(2.62 \mathrm{cmol} / \mathrm{kg}$ and $0.72 \mathrm{cmol}_{\mathrm{c}} / \mathrm{kg}$ respectively) than in the granite-derived soil $\left(0.52 \mathrm{cmol}_{\mathrm{c}} / \mathrm{kg}\right.$ and $0.27 \mathrm{cmol}_{\mathrm{c}} / \mathrm{kg}$ respectively). However, no differences were observed regarding exchangeable soil $\mathrm{Ca}$ and $\mathrm{Mg}$ at SL.

TABLE 3

Temperature regimes during the summer months at the experimental localities underlain by different soil parent materials in the Helderberg area (means for three seasons, 2006/07 to 2008/09).

\begin{tabular}{|c|c|c|c|c|c|c|}
\hline \multirow[t]{2}{*}{ Month } & \multirow[t]{2}{*}{ Locality* } & \multicolumn{3}{|c|}{ Temperature $\left({ }^{\circ} \mathrm{C}\right)$} & Temperature $>30^{\circ} \mathrm{C}$ & Temperature $<12^{\circ} \mathrm{C}$ \\
\hline & & Maximum & Minimum & Mean & \multicolumn{2}{|c|}{ hours } \\
\hline \multirow[t]{3}{*}{ December } & $\mathrm{SH}$ & 24.93 & 14.75 & 19.3 & 20 & 22 \\
\hline & $\mathrm{CL}$ & 25.52 & 15.46 & 20.3 & 22 & 7 \\
\hline & $\mathrm{CH}$ & 24.94 & 16.16 & 20.3 & 21 & 4 \\
\hline \multirow[t]{3}{*}{ January } & $\mathrm{SH}$ & 27.36 & 15.92 & 21.0 & 47 & 3 \\
\hline & $\mathrm{CL}$ & 27.65 & 16.48 & 21.7 & 47 & 2 \\
\hline & $\mathrm{CH}$ & 26.87 & 17.37 & 21.7 & 45 & 0 \\
\hline \multirow[t]{3}{*}{ February } & $\mathrm{SH}$ & 27.31 & 16.07 & 21.0 & 42 & 7 \\
\hline & $\mathrm{CL}$ & 27.83 & 16.62 & 21.7 & 47 & 0 \\
\hline & $\mathrm{CL}$ & 26.94 & 17.65 & 21.8 & 40 & 0 \\
\hline
\end{tabular}

*Refer to Table 1 for a more detailed description. 


\section{Cabernet Sauvignon}

As in the case of Sauvignon blanc, petiole $\mathrm{N}$ was not affected by the parent material, but values tended to be higher at $\mathrm{CH}$ than at CL (Table 4). Petiole P of grapevines on granitederived soils was higher than that of vines on shale-derived soils at CL. A contrasting result was observed in the soil at CL, where the shale-derived soil (300 mm soil layer) contained more than double the amount of $\mathrm{P}(28 \mathrm{mg} / \mathrm{kg})$ compared to the granite-derived soil $(12 \mathrm{mg} / \mathrm{kg})$. This pointed towards luxurious $\mathrm{P}$ uptake by grapevines on the granite-derived soil, even though the specific reason for this phenomenon was unclear. However, according to existing norms (Conradie, 1994), P was also adequately supplied to grapevines on the shale-derived soils. Petiole $\mathrm{K}$ was affected by soil parent material in both vineyards ( $\mathrm{CH}$ and $\mathrm{CL}$ ), but in a contrasting manner. Petiole K of grapevines on the granite-derived soils was higher than that of vines on the shale-derived soils at $\mathrm{CH}$, while the opposite was true at CL (Table 4). This was in accordance with exchangeable soil $\mathrm{K}$ levels being higher in granite-derived $(101 \mathrm{mg} / \mathrm{kg})$ than in shale-derived soil (78 $\mathrm{mg} / \mathrm{kg})$ at $\mathrm{CH}$, but lower in granite-derived $(87 \mathrm{mg} / \mathrm{kg})$ than in shale-derived soil $(108 \mathrm{mg} / \mathrm{kg})$ at CL. As mentioned in a previous article (Shange \& Conradie, 2012), an application of $30 \mathrm{~kg} \mathrm{~K} / \mathrm{ha} / \mathrm{yr}$ is generally recommended for vineyards in this area, but larger amounts may have been applied at some of the localities. Petiole $\mathrm{Ca}$ of the grapevines on the shalederived soils was higher than that of vines on the granitederived soils at $\mathrm{CH}$ (Table 4), thus being in agreement with the values for soluble soil Ca $(5.75 \mathrm{mg} / \mathrm{kg}$ vs. $10.9 \mathrm{mg} / \mathrm{kg})$. Petiole $\mathrm{Mg}$ of grapevines on the shale-derived soil was higher than that of vines on the granite-derived soils at $\mathrm{CH}$, while the opposite was true at CL (Table 4). Exchangeable soil $\mathrm{Mg}$ exhibited comparable trends at both sites (data not shown).

For both Sauvignon blanc and Cabernet Sauvignon grapevines, the distribution pattern of nutrients in the leaf blades (data not shown) was largely similar to that in the petioles. However, for both leaf petioles and blades, the nutritional status was not affected by soil parent material in a similar manner at the different localities, i.e. an element would be affected in a specific way at a certain locality, but not follow the same trend at another locality. This inconsistency, ascribed partly to the application of fertilisers, made it difficult to properly define the role of soil parent materials on the nutrient status of leaf blades and petioles.

\section{Juice analysis \\ Sauvignon blanc}

For the Sauvignon blanc vineyards, sugar contents were higher at SH than at SL (Table 5). This was largely due to the occurrence of Botrytis cinerea during some seasons. Juice $\mathrm{pH}$ (average for the two localities) was marginally higher for the Sauvignon blanc grapevines on granite-derived soil than those on shale-derived soils (3.30 vs. 3.23$)$, thus being in agreement with the findings of Shange (2009). Juice N was significantly higher for grapevines on shale-derived soil than on granite-derived soil at SL (Table 5). A similar trend $(343 \mathrm{mg} / \mathrm{L}$ vs. $295 \mathrm{mg} / \mathrm{L})$ could be discerned at SH. According to Gockowiak and Henschke (1992), the effect of $\mathrm{N}$ fertilisation on nitrogenous compounds in juice may be affected to a great extent by soil water status, suggesting that $\mathrm{N}$ uptake may have been enhanced by the higher waterholding capacity of the shale-derived soil, as shown by Shange and Conradie (2012).

\section{Cabernet Sauvignon}

In the case of Cabernet Sauvignon, sugar content was higher at the rain-fed locality, $\mathrm{CH}$, than at $\mathrm{CL}$, resulting in $\mathrm{pH}$ values being lower at CL (Table 5). Juice $\mathrm{N}$ was not significantly affected by soil parent material at both Cabernet Sauvignon localities; however, similarly to Sauvignon blanc, juice $\mathrm{N}$ values tended to be higher for grapevines on the shalederived than those on the granite-derived soils at both $\mathrm{CL}$ and $\mathrm{CH}$. In comparison to previously reported juice $\mathrm{P}$ values (Conradie \& Saayman, 1989; Conradie, 2001), those for Cabernet Sauvignon vines on the shale-derived soil at CL appeared to be lower. However, juice $\mathrm{P}$ values appeared to be "acceptable" for Cabernet Sauvignon grapevines at $\mathrm{CH}$ and for those on the granite-derived soil at CL. In accordance with petiole $\mathrm{P}$, juice $\mathrm{P}$ was affected by soil parent material at CL, viz. higher for juice on granite-derived soils than on shale-derived soils (Table 5). Soil parent material did not affect juice $\mathrm{K}$ significantly at any of the localities, in spite of petiole $\mathrm{K}$ having been higher for the shale-derived soil at $\mathrm{CL}$ and for the granite-derived soil at $\mathrm{CH}$. However, at the rainfed locality $(\mathrm{CH})$, juice $\mathrm{K}$ tended to be higher for grapevines on the granite-derived soil (1 $411 \mathrm{mg} / \mathrm{L}$ vs. $1298 \mathrm{mg} / \mathrm{L}$ ).

As in the case of petioles and leaf blades, parent material

\section{TABLE 4}

Petiole nutrient levels of Sauvignon blanc and Cabernet Sauvignon grapevines on granite-derived and shale-derived soils at four localities in the Helderberg area (means for five seasons, 2004/05 to 2008/09).

\begin{tabular}{|c|c|c|c|c|c|c|c|c|}
\hline \multirow{3}{*}{ Element $(\%)$} & \multicolumn{4}{|c|}{ Sauvignon blanc } & \multicolumn{4}{|c|}{ Cabernet Sauvignon } \\
\hline & \multicolumn{2}{|c|}{$\mathrm{SH}^{(1)}$} & \multicolumn{2}{|c|}{$\mathrm{SL}^{(1)}$} & \multicolumn{2}{|c|}{$\mathrm{CL}^{(1)}$} & \multicolumn{2}{|c|}{$\mathrm{CH}^{(1)}$} \\
\hline & Granite & Shale & Granite & Shale & Granite & Shale & Granite & Shale \\
\hline $\mathrm{N}$ & $0.68 \mathrm{a}^{(2)}$ & $0.74 \mathrm{a}$ & $0.72 \mathrm{a}$ & $0.67 \mathrm{a}$ & $0.54 \mathrm{~b}$ & $0.55 \mathrm{~b}$ & $0.58 \mathrm{ab}$ & $0.61 \mathrm{a}$ \\
\hline $\mathrm{P}$ & $0.47 \mathrm{~b}$ & $0.49 \mathrm{ab}$ & $0.47 \mathrm{~b}$ & $0.58 \mathrm{a}$ & $0.57 \mathrm{~b}$ & $0.35 \mathrm{c}$ & $0.93 \mathrm{a}$ & $0.82 \mathrm{a}$ \\
\hline $\mathrm{K}$ & $1.77 \mathrm{~b}$ & $1.47 \mathrm{~b}$ & $2.45 \mathrm{a}$ & $2.80 \mathrm{a}$ & $1.71 \mathrm{c}$ & $2.55 \mathrm{~b}$ & $3.56 \mathrm{a}$ & $2.04 \mathrm{c}$ \\
\hline $\mathrm{Ca}$ & $1.67 \mathrm{c}$ & $1.87 \mathrm{ab}$ & $1.73 \mathrm{bc}$ & $1.98 \mathrm{a}$ & $1.97 \mathrm{~b}$ & $1.85 \mathrm{~b}$ & $1.82 \mathrm{~b}$ & $2.21 \mathrm{a}$ \\
\hline $\mathrm{Mg}$ & $0.80 \mathrm{~b}$ & $0.95 \mathrm{a}$ & $0.64 \mathrm{c}$ & $0.82 \mathrm{~b}$ & $1.02 \mathrm{~b}$ & $0.81 \mathrm{c}$ & $1.10 \mathrm{~b}$ & $1.20 \mathrm{a}$ \\
\hline
\end{tabular}

${ }^{(1)}$ Refer to Table 1 for a more detailed description.

${ }^{(2)}$ Different letters within the same row for each cultivar denote significant differences $(\mathrm{p} \leq 0.1)$. 
did not affect juice composition in a consistent way at both the Sauvignon blanc and Cabernet Sauvignon localities, apart from juice $\mathrm{N}$ generally tending to be higher for grapevines on shale-derived soils. This suggests that soil parent material may have an effect on wine quality through its effect on fermentation rate. Levels of juice $\mathrm{K}$ were hardly affected by parent material, suggesting that it is unlikely that wine quality would have been affected on account of different $\mathrm{K}$ levels.

\section{Experimental wines \\ Sauvignon blanc}

The style and quality of Sauvignon blanc wine differed seasonally, probably on account of variations in climatic conditions (Table 2). Wine quality for the five seasons was rated from "best" to "average" and "below average", depending on the scores allocated for aroma intensity, overall quality and fullness. On the basis of the seasonal averages (Table 6), the 2004/05 vintage could be classified as "best", 2005/06, 2006/07 and 2007/08 as "average", while 2008/09 was "below average".

High values for aroma intensity, overall wine quality, fullness, fresh and cooked vegetative characteristics, as well as tropical fruit (Table 6), reflected the reason for the 2005 vintage being classified as best. Wine from the shale-derived soils received a higher score for fresh vegetative character at $\mathrm{SH}$ and for dried vegetative character at SL. This suggests that the wines from the shale-derived soils may have been marginally better, while climate-soil interactions may have been optimal during this warm and dry season. For the 2005/06 and 2006/07 seasons, when climatic conditions were classified as "dry" and "normal" respectively, wine quality was classified as average. Wine quality differed only marginally between the granite-derived and shale-derived soils in both seasons. During the 2007/08 season, when rainfall was exceptionally high (Table 2), wine quality was again classified as being of average standard. Wine from the granite-derived soil at SH scored higher for cooked vegetative character, while wine from the shale-derived soil at SL scored higher for fresh vegetative, cooked vegetative and tropical fruit characteristics. This suggests that wine from the granite-derived soil at $\mathrm{SH}$ was of superior quality in comparison to its shale-derived soil counterpart, while the reverse was true at SL. During this wet season, better drainage in the granite-derived soil may have been a positive factor at SH. The reason for a different pattern at SL was unclear, but higher acidity may have been a negative factor for wine from the granite-derived soil (Table 6). As reported previously (Shange \& Conradie, 2012), botrytis infections may also have been more severe for grapevines on the granite-derived soil, where the number of leaf layers tended to be highest.

The quality of the 2009 vintage was classified as below average, but wines from $\mathrm{SH}$ were still of better quality than those from SL, as evidenced by higher scores for overall quality and fullness (Table 6). Cooked and dry vegetative characteristics were higher for the shale-derived than for the granite-derived soils at $\mathrm{SH}$, thus being in contrast with the results from the previous season. The trend for cooked vegetative characteristics was also reversed, with wine from the granite-derived soil at SL receiving a higher score (Table 6).

The fact that the grapevines responded differently in $2007 / 08$ and 2008/09 may have been on account of rainfall not having been quite as high in 2008/09 as in 2007/08, and/ or cool conditions during the spring of 2008/09 (Table 2). In view of the different responses during the different seasons, the average values for the five seasons were reasonably similar for the individual sites (Table 6). Aroma intensity was higher for the granite-derived than the shale-derived soils at $\mathrm{SH}$, probably on account of the trends observed during the $2004 / 05$ and 2007/08 seasons. No other differences could be detected within the individual localities, but fairly large differences occurred between the two localities, with fullness and overall quality higher at SH than at SL (Table 6). This may have been due partly to SH being marginally cooler than SL. Furthermore, vineyard management was also observed visually to have been better at SH than at SL.

\section{Cabernet Sauvignon}

In comparison with Sauvignon blanc, the quality of Cabernet Sauvignon varied to a lesser extent from season to season.

TABLE 5

Juice parameters and nutrient levels of grapevines on granite-derived and shale-derived soils at Sauvignon blanc (SH, SL) and Cabernet Sauvignon (CL, CH) localities in the Helderberg area (means for five seasons, 2004/05 to 2008/09).

\begin{tabular}{|c|c|c|c|c|c|c|c|c|}
\hline \multirow{2}{*}{ Analyses } & \multicolumn{2}{|c|}{$\mathrm{SH}^{(1)}$} & \multicolumn{2}{|c|}{$\mathrm{SL}^{(1)}$} & \multicolumn{2}{|c|}{$\mathrm{CL}^{(1)}$} & \multicolumn{2}{|c|}{$\mathrm{CH}^{(1)}$} \\
\hline & Granite & Shale & Granite & Shale & Granite & Shale & Granite & Shale \\
\hline Sugar $\left({ }^{0} \mathrm{~B}\right)$ & $23.7 \mathrm{a}^{(2)}$ & $23.0 \mathrm{a}$ & $21.7 \mathrm{~b}$ & $21.7 \mathrm{~b}$ & $22.9 \mathrm{~b}$ & $23.2 \mathrm{~b}$ & $24.1 \mathrm{a}$ & $23.9 \mathrm{a}$ \\
\hline TTA $(\mathrm{g} / \mathrm{L})$ & $7.92 \mathrm{~b}$ & $8.66 \mathrm{a}$ & $8.48 \mathrm{a}$ & $8.18 \mathrm{ab}$ & $7.46 \mathrm{a}$ & $7.12 \mathrm{a}$ & $7.60 \mathrm{a}$ & $7.56 \mathrm{a}$ \\
\hline $\mathrm{pH}$ & $3.23 \mathrm{bc}$ & $3.15 \mathrm{c}$ & $3.37 \mathrm{a}$ & $3.31 \mathrm{ab}$ & $3.22 \mathrm{c}$ & $3.31 \mathrm{bc}$ & $3.59 \mathrm{a}$ & $3.51 \mathrm{ab}$ \\
\hline $\mathrm{N}(\mathrm{mg} / \mathrm{L})$ & $295 \mathrm{a}$ & $343 \mathrm{a}$ & $184 \mathrm{~b}$ & $281 \mathrm{a}$ & $258 \mathrm{~b}$ & $289 \mathrm{ab}$ & $301 \mathrm{ab}$ & $342 \mathrm{a}$ \\
\hline $\mathrm{P}(\mathrm{mg} / \mathrm{L})$ & $51.31 \mathrm{a}$ & $53.01 \mathrm{a}$ & $59.33 \mathrm{a}$ & $61.38 \mathrm{a}$ & $133 \mathrm{a}$ & $78.50 \mathrm{~b}$ & $132 \mathrm{a}$ & $124 \mathrm{a}$ \\
\hline $\mathrm{K}(\mathrm{mg} / \mathrm{L})$ & $1031 \mathrm{a}$ & $1054 \mathrm{a}$ & $1235 \mathrm{a}$ & $1218 \mathrm{a}$ & $1201 \mathrm{a}$ & $1185 \mathrm{a}$ & $1411 \mathrm{a}$ & $1298 \mathrm{a}$ \\
\hline $\mathrm{Ca}(\mathrm{mg} / \mathrm{L})$ & $37.0 \mathrm{a}$ & $39.5 \mathrm{a}$ & $39.3 \mathrm{a}$ & $31.3 \mathrm{a}$ & $36.2 \mathrm{a}$ & $44.5 \mathrm{a}$ & $36.9 \mathrm{a}$ & $59.3 \mathrm{a}$ \\
\hline $\mathrm{Mg}(\mathrm{mg} / \mathrm{L})$ & $86.9 \mathrm{a}$ & $84.0 \mathrm{a}$ & $77.5 \mathrm{ab}$ & $66.1 \mathrm{~b}$ & $94.1 \mathrm{a}$ & $95.2 \mathrm{a}$ & $101.0 \mathrm{a}$ & $89.5 \mathrm{a}$ \\
\hline
\end{tabular}

${ }^{(1)}$ Refer to Table 1 for a more detailed description.

${ }^{(2)}$ Different letters within the same row for each cultivar denote significant differences $(\mathrm{p} \leq 0.1)$. 


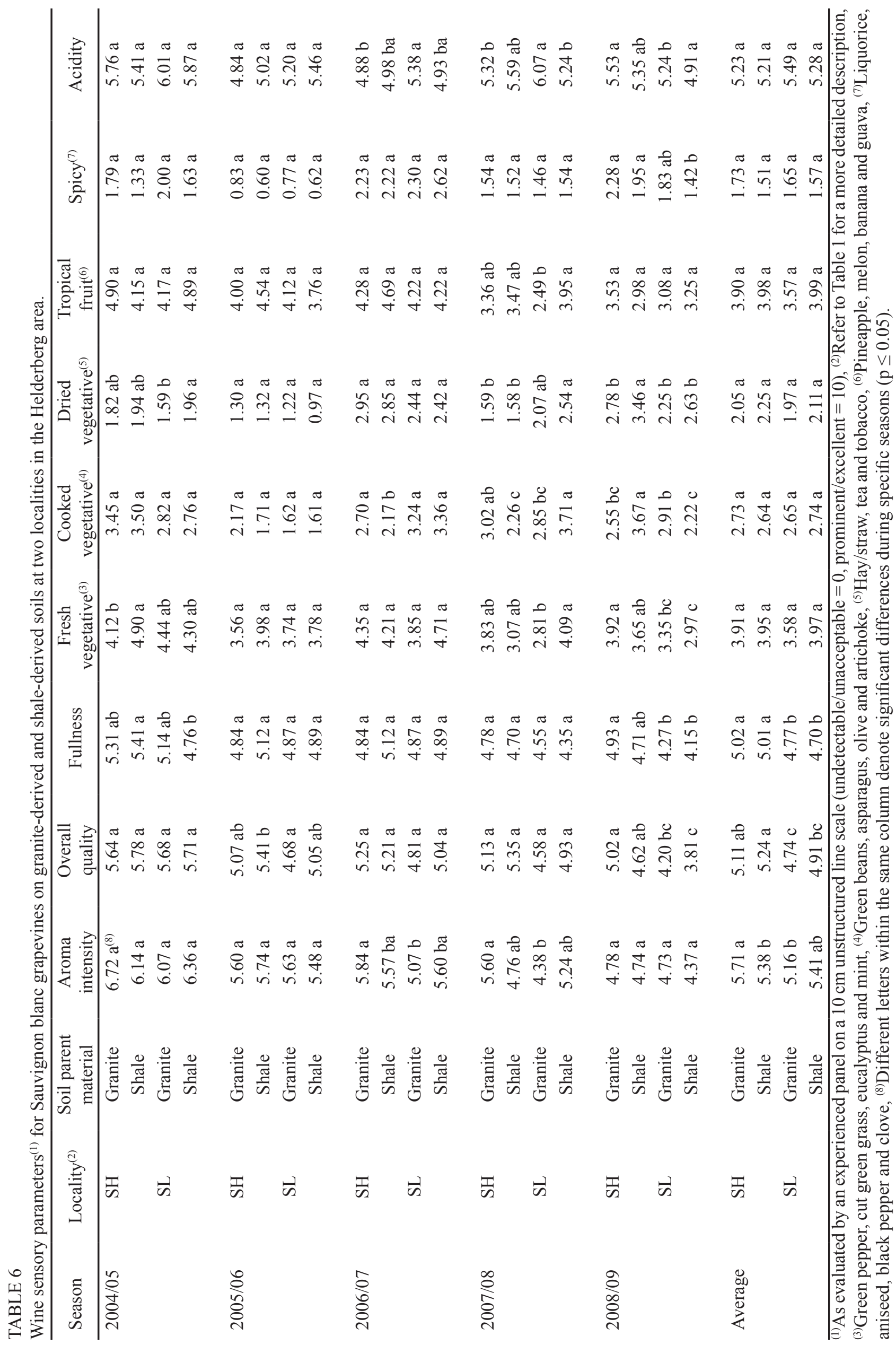


Scores for overall quality, aroma intensity and fullness pointed towards "average" quality during the three "dry" seasons (2004/05, 2005/06 and 2006/07), as well as during one of the "wet" seasons (2008/2009). However, wine quality was "below average" during the other "wet" season (2007/08). Results as obtained at the different experimental localities over the five-year period are shown in Table 7.

In contrast to Sauvignon blanc, the 2005 vintage for Cabernet Sauvignon was not designated as the best. No major effects of soil parent material could be identified. However, vegetative and berry characteristics tended to be highest for wine from the shale-derived soil at CL. Aroma intensity, overall quality and fullness were highest for the 2006 vintage wine from the shale-derived soil at $\mathrm{CL}$, suggesting that the "best" wine (most typical of Cabernet Sauvignon) was produced from the shale-derived soil at this site. This implied that the higher water-holding capacity of the shalederived soil may have been beneficial for wine quality during this dry season. Differences were less pronounced at $\mathrm{CH}$, with vegetative character higher for wine from the granitederived soil (Table 7). Berry character for wines from the granite-derived soil was highest during the 2006/07 season ("normal" climatic conditions) at CL, suggesting that wine style may have been more typical of Cabernet Sauvignon in comparison to wine from the shale-derived soil.

In the 2007/08 season, with quality being "below average", the effects of soil parent material were fairly prominent at both sites. Wine from the granite-derived soil at CL received higher scores for aroma intensity, overall quality, fullness and berry characteristics, with wine from this soil also scoring the highest for overall quality and fullness at $\mathrm{CH}$ (Table 7). During this particularly wet season, wine quality for grapevines on granite-derived soils appeared to have been enhanced. Soil parent material effects were again fairly prominent for the 2009 vintage, with wines being of acceptable quality (Table 7). Aroma intensity, overall quality, fullness, and berry and spicy characteristics for wines from the granite-derived soils were highest at CL, thus being in agreement with the results obtained during the previous season. Soil parent material effects were less prominent at $\mathrm{CH}$ than during the previous season, possibly on account of a "levelling" effect of low spring temperatures (Table 2). However, wine from the granite-derived soil was still "best" in terms of higher scores for vegetative and spicy characteristics. Wine quality and/or style were not affected by soil parent material when averages for the five seasons were compared for individual sites (Table 7), possibly due to seasonal variations. However, the vegetative character tended to be higher and berry characteristics lower for wine from the granite-derived soils at the rain-fed site $(\mathrm{CH})$.

The above-mentioned results suggest that the style and/ or quality of Sauvignon blanc and Cabernet Sauvignon wines were affected to some extent by differences in soil parent material. Responses obtained during the different seasons, may be summarised as follows:

2004/05: Wine style and/or quality tended to be best for shale-derived soils at three of the sites (SH, SL and CL), while no differences could be detected at $\mathrm{CH}$. The higher water-holding capacities of the shale-derived soils may have been a positive factor during this dry season.

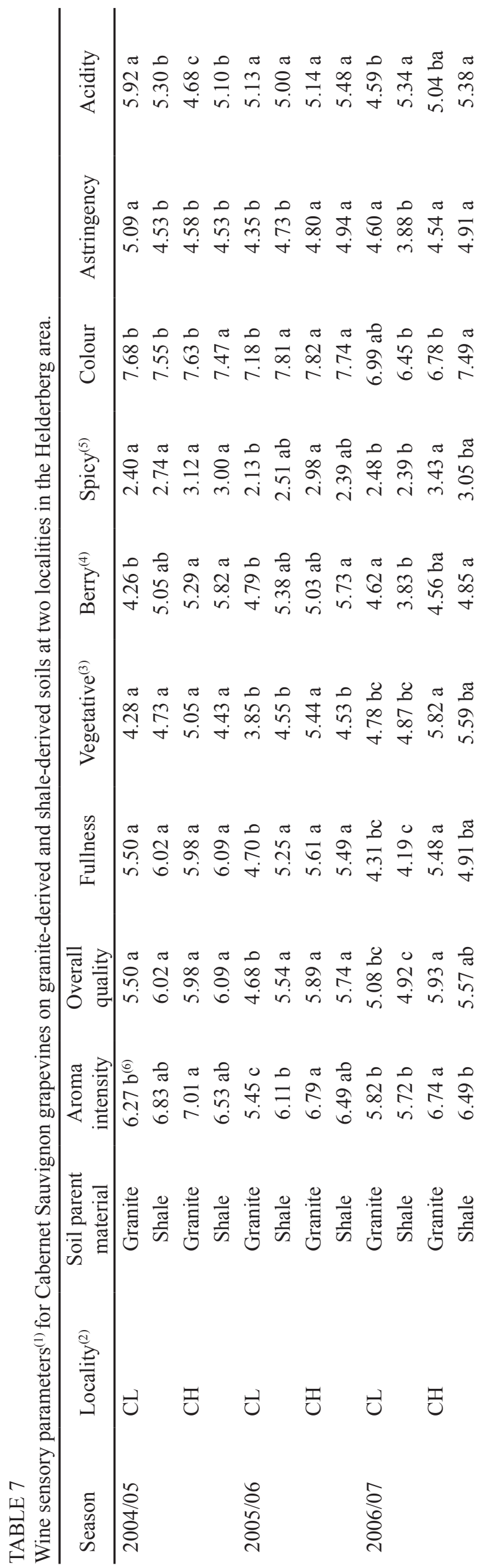




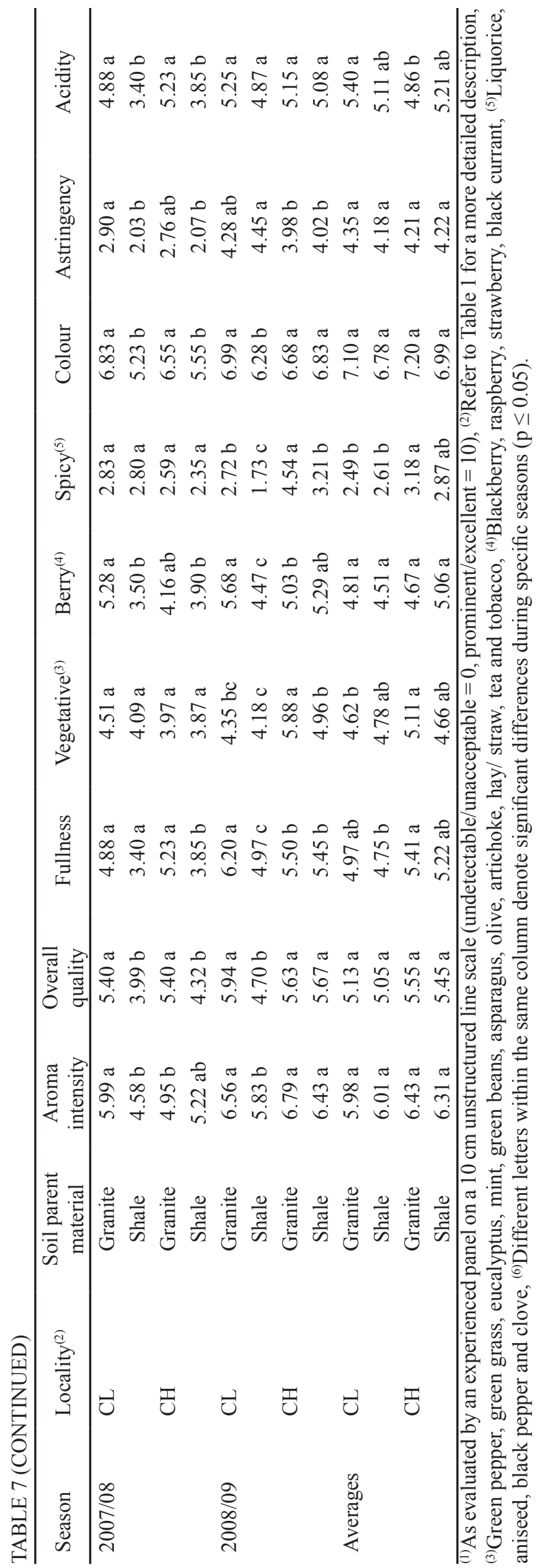

2005/06: Rainfall was below average, but not as dry as in 2004/05. Wine style and/or quality were best for the shalederived soil at CL, but no effect of soil parent material could be detected at the other sites.

2006/07: Rainfall was normal, but spring temperatures were high. Wine style and/or quality were best for the granitederived soil at CL, with no differences at the other sites.

2007/08: Wine style and/or quality were best for the granitederived soils at $\mathrm{SH}, \mathrm{CH}$ and $\mathrm{CL}$, while wine from the shalederived soil was best at SL. As already mentioned, better drainage of the granite-derived soil may have been a positive factor during this very wet season. The reason for the different pattern at SL is unclear, but at this locality botrytis infection may have been more severe for grapevines on the granite-derived soil.

2008/09: Rainfall was again high, wine style and/or quality were highest for the granite-derived soils at SL, CH and CL, while quality was highest for the shale-derived soil at $\mathrm{SH}$. The fact that the grapevines at $\mathrm{SH}$ responded differently in 2007/08 and 2008/09 may have been on account of rainfall not having been quite as high in 2008/09 as in 2007/08, and/ or cool conditions during the spring of 2008/09 (Table 2).

\section{CONCLUSIONS}

Juice $\mathrm{N}$ of the grapevines on the shale-derived soils tended to be higher than that of vines on the granite-derived soils. Soil parent material may therefore have an effect on wine quality, through its effect on fermentation rate. This warrants further investigation. In this study, juice $\mathrm{K}$ was hardly affected by soil parent material. However, soil preparation before planting, as well as $\mathrm{K}$ fertilisation, may have negated the effect of parent material to some extent. Wine style and/ or quality of Sauvignon blanc seems to be affected by soil parent material differences to a lesser extent than that of Cabernet Sauvignon. However, wine style and/or quality of Cabernet Sauvignon was not affected by soil parent material in a consistent manner. During dry seasons the higher waterholding capacity of the shale-derived soils may affect wine quality positively. In contrast, better wine seems to be obtained from granite-derived soil during cooler and wetter seasons. This suggests that the extent of the effect of the soil parent material on wine style and/or quality turns out to be determined by seasonal weather conditions.

\section{LITERATURE CITED}

Amerine, M.A. \& Winkler, A.J., 1944. Composition and quality of musts and wines of Californian grapes. Hilgardia 15, 493-673.

Campbell, C.R. \& Plank, C.O., 1998. Preparation of plant tissue for laboratory analysis. In: Y.P. Kalra (ed). Handbook of reference methods for plant analysis. CRC Press, Boca Raton. pp. $37-49$.

Conradie, W.J., 1994. Vineyard fertilisation. Proceedings of the work session on vineyard fertilisation. ARC-Fruit, Vine and Wine Research Institute, Private Bag X5026, 7599 Stellenbosch, South Africa.

Conradie, W.J., 2001. Timing of nitrogen fertilization and the effect of poultry manure on the performance of grapevines on sandy soil. II. Leaf analysis, juice analysis and wine quality. S. Afr. J. Enol. Vitic. 22, 60-68.

Conradie, W.J. \& Saayman, D., 1989. Effects of long-term nitrogen, phosphorus and potassium fertilization on Chenin blanc vines. II. Leaf analyses and grape composition. Am. J. Enol. Vitic. 40, 91-98. 
Conradie, W.J., Carey, V.A., Bonnardot, V., Saayman, D. \& Van Schoor, L.H., 2002. Effect of different environmental factors on the performance of Sauvignon blanc grapevines in the Stellenbosch/Durbanville districts of South Africa. I. Geology, soil, climate, phenology and grape composition. S. Afr. J. Enol. Vitic. 23, 78-91.

Gockowiak, H. \& Henschke, P., 1992. Nitrogen composition of grape juice and implications for fermentation: results of a survey made in N-E Victoria. Aust. Grapegrower \& Winemaker 340, 131-138.

Kodur, S., 2011. Effects of juice $\mathrm{pH}$ and potassium on juice and wine quality, and regulation of potassium in grapevines through rootstocks (Vitis): a short review. Vitis, 50, 1-6.

Miller, R.O., 1998. High temperature oxidation: dry ashing. In: Y.P. Kalra (ed). Handbook of reference methods for plant analysis. CRC Press, Boca Raton. pp. $53-56$.

Mpelasoka, B.S., Schachtman, D.P., Treeby, M.T. \& Thomas, M.R., 2003. A review of potassium nutrition in grapevines with special emphasis on berry accumulation. Aust. J. Grape Wine Res. 9, 154-168.

Myburgh, P.A., 2011. Response of Vitis vinifera L. $c v$. Merlot to low frequency irrigation and partial root zone drying in the Western Cape Coastal Region - Part II. Vegetative growth, yield and quality. S. Afr. J. Enol. Vitic. 32, 104-116.

Noble, A.C., Arnold, R.A., Buechsenstein, J., Leach, E.J., Schmidt, J.O. \& Stern, M., 1987. Modification of a standardized system of wine aroma terminology. Am. J. Enol. Vitic. 38, 143-146.

SAS, 2000. SAS/STAT Users Guide, Version $8,1^{\text {st }}$ Printing. Vol 2. SAS Institute Inc, SAS Campus Drive, North Carolina, USA.

Seguin, G., 1983. Influence des terroirs viticoles sur la constitution et la qualité des vendages, Bull. OIV 56 (627), 8-12.

Shange, L.P., 2009. Nutritional status of geologically different vineyards. MSc thesis, Stellenbosch University, Private Bag X1, 7602 Matieland, South Africa.
Shange, L.P. \& Conradie, W.J., 2012. Effects of soil parent material and climate on the performance of Vitis vinifera L. cv. Sauvignon blanc and Cabernet Sauvignon - Part I. Soil analysis, soil water status, root system characteristics, plant water status, cane mass and yield. S. Afr. J. Enol. Vitic. $33,161-173$.

Shapiro, S.S. \& Wilk, M.B., 1965. An analysis of variance test for normality (complete samples). Biometrika 52, 591-611.

Snedecor, G.W. \& Cochran, W.G., 1980 ( $7^{\text {th }}$ ed). Statistical methods. The IOWA State University Press, Ames, Iowa.

Somers, T.C., 1975. In search of quality for red wines. Food Tech. Aust. $27,49-56$

Theron, J.N., Gresse, P.G., Siegfried, H.P. \& Rogers, J., 1992. The geology of the Cape Town Area. Explanation of Sheet 3318. Department of Mineral and Energy Affairs, Pretoria, South Africa.

Van Schoor, L.H., 2001. Geology, particle size distribution and clay fraction mineralogy of selected vineyard soils in South Africa and the possible relationship with grapevine performance. MSc thesis, Stellenbosch University, Private Bag X1, 7602 Matieland (Stellenbosch), South Africa.

Wilson, J.E., 1998. Terroir. The role of geology, climate and culture in the making of French wines. University of California Press, Berkeley, California.

Winkler, A.J., Cook, J.A., Kliewer, W.M. \& Lider, L.A., 1974 (2 $2^{\text {nd }}$ ed). General viticulture. University of California Press, Berkeley, California.

Wooldridge, J., 1988. The potassium supplying power of certain virgin upland soils of the Western Cape. MSc thesis, Stellenbosch University, Private Bag X1, 7602 Matieland, South Africa. 